\title{
The need for an intrusion upon seclusion privacy tort within English law
}

\author{
John Hartshorne
}

\begin{abstract}
In the United States, New Zealand, and the Canadian province of Ontario recognition has been afforded to privacy torts remedying intrusions upon seclusion or solitude, and the creation of such a tort has also been recommended by the Australian Law Reform Commission. In England and Wales recognition has so far only been afforded to a privacy tort remedying misuse of private information. This article considers the current prospects for the recognition of an intrusion upon seclusion tort within English law. It will be suggested that there is less necessity for such recognition following the apparent recent confirmation by the decisions in Gulati $v$ MGN and Vidal-Hall $v$ Google that misuse of private information claims may still be brought where there is no ensuing publication of wrongly acquired private information. Given that intrusions commonly result in the acquisition of private information, it will be suggested that many of the privacy interests protected by the intrusion torts in other jurisdictions may now therefore be protected in English law through a claim for misuse of private information.
\end{abstract}

\section{Keywords}

Torts, privacy, intrusion upon seclusion, misuse of private information

\section{Introduction}

The concept of privacy is an elusive one, and attempts to explain or define it have generated fierce academic debates and a sprawling literature across the common law world. ${ }^{1}$ Numerous committees have also grappled with these difficulties. ${ }^{2}$ Despite the challenges presented in this area, in recent years there have been significant developments across common law jurisdictions concerning the extent to which the law of tort is able to afford a remedy to individual citizens following an invasion of their deemed 'privacy' interests. In both England and Wales and New Zealand torts now exist that are capable of redressing violations of citizens' 'informational privacy' interests. For the purposes of

Leicester Law School, University of Leicester, UK 
this article two developments that are of particular significance are the recognition within New Zealand and the Canadian province of Ontario of torts redressing violations of the so called 'seclusion or solitude' of citizens. Moreover, although the Australian High Court has so far failed to afford clear recognition to any tort offering explicit protection for privacy, ${ }^{3}$ in a significant move the Australian Law Reform Commission in 2014 recommended the introduction of a statutory tort capable of remedying both a misuse of private information and an intrusion upon the seclusion of citizens, "such as by physically intruding into ... private space or by watching, listening to or recording ... private activities or private affairs' (2014: para. 5.8). The aim of this article is to assess the extent to which English law may in due course afford similar recognition to a tort redressing intrusions upon seclusion. It will be contended that such a development is in fact unlikely to occur in the near future. This is due, principally, to the ramifications of the significant decisions in the Vidal-Hall $v$ Google ${ }^{4}$ litigation which, it will be argued, suggest that claims for misuse of private information may now be brought where private information is simply inappropriately acquired, without any ensuing publication. The same implications appear to follow from the litigation in Gulati $v M G N .{ }^{5}$ Given that the majority of intrusions upon seclusion occur with a view to acquiring information, it will be suggested that these decisions now make it possible for very many intrusions to be remedied in English law through use of the established action for misuse of private information.

\section{The provenance and character of the information/intrusion distinction within privacy jurisprudence}

Despite the vagueness of the concept of privacy, two particular ways in which civil remedies have been constructed for redressing violations of privacy have centred upon the distinction between violations of informational privacy, and intrusions upon some sort of private realm, or state of seclusion, that a citizen enjoyed at the material time. The origin of this distinction lies in the jurisprudence and scholarship of the United States (US). Around the turn of the $20^{\text {th }}$ century a body of jurisprudence began to emerge in the US addressing the question of whether remedies for invasions of privacy should exist within state law. These discussions had been catalysed by the seminal article written by Warren and Brandeis in the Harvard Law Review (1890), where the learned authors had powerfully argued that several existing causes of action could in fact be understood as being underpinned by a principle of privacy, and that there was now a need for the formal recognition of such a right within US law. Seventy years later, in an article which has proven to be as seminal as that of Warren and Brandeis, Prosser undertook an analysis of the privacy jurisprudence as it had developed since Warren and Brandeis' article, and advanced the following proposition (1960: 389): 
What has emerged from the decisions is no simple matter. It is not one tort, but a complex of four. The law of privacy comprises four distinct kinds of invasion of four different interests of the plaintiff, which are tied together by the common name, but otherwise have almost nothing in common except that each represents an interference with the right of the plaintiff, in the phrase coined by Judge Cooley, "to be let alone." 6

Prosser described this 'complex' of four torts in the following terms (1960: 389):

1. Intrusion upon the plaintiff's seclusion or solitude, or into his private affairs.

2. Public disclosure of embarrassing private facts about the plaintiff.

3. Publicity which places the plaintiff in a false light in the public eye.

4. Appropriation, for the defendant's advantage, of the plaintiff's name or likeness.

Prosser's taxonomy was eventually incorporated into the Second Edition of the American Law Institute's Restatement of Torts (volume 3, 1977), and proved to be hugely influential upon the further development of state law. ${ }^{7}$ Because privacy torts were developed in the US much earlier than they were in other common law jurisdictions, Prosser's classification has, as we shall see, proved to be equally influential elsewhere. Thus far, however, it is mainly the first two torts referred to by Prosser that have gained traction outside of the US. Full exploration of the possible reasons for this lies outside the scope of this article, ${ }^{8}$ but it is notable that even Prosser himself was sceptical of the legitimacy of the third and fourth torts described by him. As to the third, Prosser strained to divine the relationship between this tort and the more established tort of defamation (1960: 400 and 422); as to the fourth, it seemed to Prosser that this had more to do with the protection of proprietary interests and interests in intellectual property, than with any 'right to be let alone' (1960: 406 and 423). At this juncture it will be helpful to explain the character of the first two torts described by Prosser.

\section{Intrusion upon the plaintiff's seclusion or solitude, or into their private affairs}

The Restatement explains that this tort consists solely of an intentional interference with a person's interest in solitude or seclusion (either as to their person or as to their private affairs or concerns) of a kind that would be highly offensive to a reasonable person. ${ }^{9}$ There appear to be two limbs of potential interference. The first consists of physically intruding into a private space where someone is in a state of seclusion. A classic illustration referred to by Prosser is De May $v$ Roberts ${ }^{10}$ where the defendant physician inappropriately allowed an acquaintance to be present in a room where he was delivering the plaintiff's baby. It seems this limb also embraces an intrusion upon a person's bodily privacy. So in Hill $v$ McKinley ${ }^{11}$ a finding of liability by an Iowa jury was upheld where police officers had strapped the plaintiff to a restraining board whilst she was naked, and then inappropriately left her in this state for three hours. The second limb consists of the 
use of the senses (whether assisted by aids such as binoculars or not) to oversee or overhear a person's private affairs. This covers, for example, looking into their bedroom window, opening their post, or gaining access to their banking information. ${ }^{12}$ To illustrate, in Lawlor v North American Corp of Illinois ${ }^{13}$ the Supreme Court of Illinois gave recognition to the intrusion tort in the context of a claim by the plaintiff that her former employer had used a private investigator to obtain records of her personal home and mobile telephone calls. A significant point in the context of this article is to be found in the 'comment' upon this tort in the Restatement, where it is stated: 'The intrusion itself makes the defendant subject to liability, even though there is no publication or other use of any kind of the ... information'. ${ }^{14}$ So in Hamberger $v$ Eastman ${ }^{15}$ it was held by the Supreme Court of New Hampshire that the installation in the plaintiffs' bedroom of a bugging device by their landlord represented an intrusion upon their solitude or seclusion, irrespective of any averment on their part that anyone had listened to or overheard any sounds or voices originating therefrom.

\section{Public disclosure of embarrassing private facts about the plaintiff}

According to the Restatement, this tort addresses the disclosure of true private facts which would be highly offensive to a reasonable person. ${ }^{16}$ In McCabe v Village Voice,${ }^{17}$ for example, it was conceded before the Eastern District Pennsylvania court that the publication in the defendant's weekly newspaper of a photograph of the plaintiff lying naked in a bath would meet these criteria where the plaintiff had been given to believe that the photograph would only be printed in a book. It is stressed in the 'comment' to this section that liability is dependent upon publicity being given to the private facts, which requires 'that the matter is made public, by communicating it to the public at large, or to so many persons that the matter must be regarded as substantially certain to become one of public knowledge. ${ }^{18}$ Where there is an intrusion upon seclusion, which then results in publicity being given to any true private facts acquired during the intrusion, liability may arise under both the intrusion and the public disclosure torts, although this would not result in double recovery of damages. ${ }^{19}$ However without the public disclosure of facts no independent liability will arise under the disclosure tort, ${ }^{20}$ meaning that the mere acquisition of facts pertaining to the private life of another will not suffice. It is undoubtedly this feature that drove Prosser to observe of this tort that the interest protected is that of reputation, with the same overtones of mental distress that are present in libel and slander. It is in reality an extension of defamation' (1960: 398). This focus upon the need for publicity, and for it to be highly offensive to a reasonable person, suggests a concern with how the plaintiff is perceived by others, rather than with how the plaintiff might themselves feel about an interference with the management of their personal information.

\section{The recognition of intrusion upon seclusion torts outside the US}




\section{Canada}

The province of Ontario was the first jurisdiction to afford recognition at the appellate court level to a common law tort of intrusion upon seclusion, ${ }^{21}$ in the case of Jones $v$ Tsige. ${ }^{22}$ Prior to this decision none of Prosser's torts had been recognised within Ontario by an appellate court, although in lower court decisions there had apparently been recognition of both the intrusion tort ${ }^{23}$ and the appropriation of personality tort ${ }^{24}$ (and subsequent to the decision in Jones the disclosure of embarrassing private facts tort has also been recognised by an Ontario lower court judge). ${ }^{25}$ The plaintiff in Jones was an employee of a bank who became aware that her personal banking records had been accessed on many occasions by a fellow employee, who was involved in a relationship with the plaintiff's former husband. Of particular significance to the case was the Ontario Court of Appeal's observation that the defendant had not in any way published, distributed or recorded the wrongly acquired financial information. As part of his reasoning Sharpe JA, delivering the lead judgment of the court, considered Prosser's article and accepted his 'insight that the general right to privacy embraces four distinct torts, each with its own considerations and rules, and that confusion may result from a failure to maintain appropriate analytic distinctions between the categories. ${ }^{26}$ Sharpe JA concluded that the tort that was most relevant to the claim before the court was that of intrusion upon seclusion. After considering a range of material relating to the Canadian Charter of Rights and Freedoms and provincial law, Sharpe JA identified privacy as an important underlying and animating value of various existing legal protections, and determined that it was therefore appropriate for the court to take the step of confirming the existence of a right of action for intrusion upon seclusion. ${ }^{27}$ In framing this new right, Sharpe JA then effectively took it 'off the shelf' of the Restatement:

The key features of this cause of action are, first, that the defendant's conduct must be intentional, within which I would include reckless; second that the defendant must have invaded, without lawful justification, the plaintiff's private affairs or concerns; and third, that a reasonable person would regard the invasion as highly offensive causing distress, humiliation or anguish. ${ }^{28}$

On the facts the claim was deemed to be made out, and summary judgment was entered for the plaintiff.

\section{New Zealand}

The precedent established in Jones helped set the scene for the advancement of a similar argument before the High Court of New Zealand in $C v$ Holland. ${ }^{29}$ The claim was brought after the plaintiff discovered that the defendant, a man living in the same house as her, had secretly installed a video camera in the roof space above a bathroom, and then taken video footage of her showering. Whilst it seemed patent that the defendant himself had viewed the footage, there was no suggestion that he had published the video clips or 
shown them to anyone else. By the time of the hearing a tort of wrongful publication of private facts had been established in New Zealand, following the decision of the Court of Appeal in Hosking $v$ Runting. ${ }^{30}$ However the emphasis in Hosking upon the need for publicity to be given to the private facts forced the trial judge in $C v$ Holland, Whata $\mathrm{J}$, to assert that: 'In the absence of threatened publication, the Hosking privacy tort has no direct application to the present facts. ${ }^{31}$ Whata $\mathrm{J}$ therefore embarked upon an analysis of the extent to which it would be possible to develop the common law in order to afford recognition to an intrusion upon seclusion tort. One may speculate as to why Whata $\mathrm{J}$ didn't alternatively explore the extent to which the claim could have been accommodated within the private facts tort, via a dropping of the strict requirement for publicity to be given to the private facts; indeed this might have entailed a more modest development of the common law than the recognition within New Zealand of an entirely novel intrusion upon seclusion tort. The explanation, it appeared, once again laid in the influence that Prosser's categorisation had cast over the proceedings. Having analysed domestic and comparative legal material, Whata $J$ was content to conclude that: 'I have reached the view that it is functionally appropriate for the common law to establish a tort equivalent to the North American tort of intrusion upon seclusion'; ${ }^{32}$ and 'that the most appropriate course is to maintain as much consistency as possible with the North American tort given the guidance afforded from existing authority. ${ }^{33}$ Whata $\mathrm{J}$ rejected what he described as a 'simple reasonable expectation of privacy test' ${ }^{34}$ as this would be insufficiently prescriptive for establishing clear boundaries for judicial interventions following alleged invasions of privacy. The elements of the fledging tort were framed by Whata $\mathrm{J}$ in terms subtly different to those articulated in the Restatement and Jones $v$ Tsige, because his Honour inserted an additional reasonable expectation of privacy requirement: '(a) An intentional and unauthorised intrusion; (b) Into seclusion (namely intimate personal activity, space or affairs); (c) Involving infringement of a reasonable expectation of privacy; (d) That is highly offensive to a reasonable person. ${ }^{35}$ Applying these elements to the facts, the defendant was found to be liable for the intrusion upon the plaintiff's seclusion.

\section{Australia}

Whilst no privacy tort has yet been afforded explicit recognition by an Australian appellate court, $^{36}$ in 2014 the Australian Law Reform Commission (ALRC) recommended the introduction of a statutory tort of privacy via Commonwealth legislation. The ALRC recommended that the proposed Act should address two forms of invasion of privacy: intrusion upon seclusion; and misuse of private information. Intrusion would cover 'physically intruding into the plaintiff's private space or by watching, listening to or recording the plaintiff's private activities or private affairs' (2014: 74), whereas misuse of information would cover 'collecting or disclosing private information about the plaintiff' (2014: 74). The ALRC said that these two categories 'are 
widely considered to be the core of a right to privacy' (2014: para. 5.4). In selecting these the ALRC acknowledged that it had drawn on the categorisation adopted in the US. The ALRC accepted that there could be overlap situations giving rise to liability under both heads. However it is suggested that the ALRC created the potential for a significant conceptual blurring of these categories by further recommending that liability for misuse of private information need not be dependent upon publicity being given to the collected private information, in contrast with the position prevailing under the equivalent US and New Zealand torts. The ALRC stated that it considered it reasonable not to confine the misuse of private information tort in this way as 'some other type of misuse of private information may invade a person's privacy' (2014: para. 5.45), including 'wrongfully obtaining it' (2014: para. 5.37). Yet given that private information will typically be 'wrongfully obtained' through 'physically intruding into the plaintiff's private space or by watching, listening to or recording the plaintiff's private activities or private affairs', this removal of the publicity requirement surely risks collapsing the informational tort into the intrusional variety, and potentially vice versa. The ALRC commented that ' $[\mathrm{t}] \mathrm{he}$ US tort of intrusion has been said to focus on "the means of obtaining private information rather than on the publication of the information so gained. The core of the tort is the offensive prying into the private domain of another"' (2014: para. 5.26). ${ }^{37}$ But under the ALRC's proposals it would seem that a sharp knife may be required in order to separate intrusions (offensive prying) from 'wrongfully obtaining' private information. In reality the ALRC's proposals could therefore produce a situation where victims of invasions of privacy would be well advised to plead under both heads, which rather begs the question of whether a more general approach might have been preferable, such as one based upon reasonable expectations of privacy. For present purposes, however, what is most pertinent is that if these recommendations are adopted, then Australia will become aligned with the US, Ontario and New Zealand in recognising a discrete intrusion upon seclusion tort, in contrast with the position which has thus far prevailed in England and Wales.

\section{The position in England and Wales to date}

As mentioned in the introduction, English tort law now recognises an action for misuse of private information (MOPI), a development which was catalysed by the introduction of the Human Rights Act 1998 (HRA) and the seminal decision of the House of Lords in Campbell $v$ MGN. ${ }^{38}$ Confirmation that the MOPI action should be classified as a tort was ostensibly provided by the Court of Appeal in the Vidal-Hall $v$ Google litigation, discussed more fully later on in this article. On the classification point their Lordships were strictly concerned with whether MOPI was a tort for the purposes of serving a claim form outside of England and Wales. However their Lordships added that their decision did not 'create a new cause of action. In our view, it simply gives the correct legal label 
to one that already exists. ${ }^{39}$ This suggested that the 'tort label' was being affixed more generally, rather than purely for the purposes of service out of the jurisdiction. So far there has been no explicit recognition within England and Wales of a discrete tort addressing intrusions upon seclusion. There may be several explanations for this position, which Bennett (2014) has described as being 'out of kilter' with that in the US, and 'somewhat crabbed' in light of the Canadian and New Zealand developments' (2014: 305). First, there has been a lack of reference to Prosser's categorisation within the English caselaw over the period in which judges have been strengthening protection for privacy. As a consequence his scheme, and its associated terminology, has failed to exert the degree of influence over English developments which it has elsewhere. If one reads the decision of their Lordships in Campbell, for example, the position in the US is referred to only fleetingly. Secondly, and inextricably related to the foregoing, because the English judiciary has been developing the law via a traditional method of incremental development, utilising the existing law as the stepping stone in this process, this has limited the scope for the importation of concepts and terminology established under entirely separate legal regimes. For example because the action which is now referred to as MOPI was incrementally developed out of the English action for breach of confidence, it was initially (and to a certain extent still is) populated with concepts and terminology redolent of that action.

A third possibility is that the spectre of the decision in Wainwright $v$ Home Office, ${ }^{40}$ where the House of Lords declined to afford recognition to a general tort of privacy, might have injected a sense of judicial caution over the development of privacy law in England. In the leading judgment in Wainwright Lord Hoffmann cautioned against the judiciary encroaching upon the terrain of Parliament in matters concerning the creation of potentially controversial new rights. On this Lord Hoffmann quoted with approval from the judgment of Sir Robert Megarry V-C in Malone v Metropolitan Police Comr, where his Lordship had said: 'The extension of the existing laws and principles is one thing, the creation of an altogether new right is another.' 41 Accordingly, albeit perhaps overstating the matter, in Campbell Baroness Hale asserted that: "the courts will not invent a new cause of action to cover types of activity which were not previously covered: see Wainwright $v$ Home Office ... That case indicates that our law cannot, even if it wanted to, develop a general tort of invasion of privacy. ${ }^{42}$

A fourth explanation undoubtedly lies in the role that the HRA and European Convention on Human Rights (ECHR) played during these developments. Although the English judiciary has so far successfully avoided explicitly answering the question of what, if any, form of horizontal effect has been afforded to ECHR rights via the HRA, ${ }^{43}$ at the very least there does appear to have been in operation some form of what Phillipson (1999) has described as 'weak indirect horizontal effect', whereby the judiciary has taken account of the values represented by the ECHR when applying and developing the 
existing law. In this respect therefore English judges have been encouraged to look across the English Channel towards the European Court of Human Rights (ECtHR) in Strasbourg, and to utilise the admittedly vague concepts within the Article 8 jurisprudence, rather than to seek inspiration from the opposite shores of the Atlantic Ocean. Thus in McKennitt $v$ Ash Buxton LJ declared in the context of a claim for MOPI that Arts 8 and 10 of the ECHR 'are the very content of the domestic tort that the English court has to enforce'. ${ }^{44}$ This anchorage to the ECHR has avoided the straightjacketing of developments within Prosser's categorisation, which in due course may allow the judiciary to strengthen protection for privacy without becoming ensnared by the complications attendant in an information/intrusion bifurcation.

Finally, it may possibly be the position that no intrusion tort has so far been recognised in England because an appropriate case has not yet presented itself where such a development could occur. One possible candidate was Wainwright itself, where prison officers conducted unlawful strip-searches upon prison visitors. The facts of this case sat uncomfortably within an informational paradigm, because although the prison officials were able to observe the claimants in virtually naked states, they would have acquired this information in any event had they conducted their searches lawfully, albeit that under the search rules the claimants would have been required to expose only one half of their bodies at a time. It is possible that the House of Lords might have been more favourably disposed towards this case had the claimants more modestly pleaded for the recognition of an intrusion upon seclusion tort, instead of ambitiously pleading for the recognition of a general tort of privacy. However more recently in Gulati and Vidal-Hall cases have presented themselves which in the US would have sat squarely within the intrusion upon seclusion category. Yet, as we shall see later, the claimants chose to pursue their claims, inter alia, in MOPI.

\section{Shoots of promise for an intrusion tort within English law?}

Before considering the decisions in Gulati and Vidal-Hall and their implications for English law, it is first worth briefly noting certain prior developments that had been occurring in the caselaw, which offered some suggestion that English law could be gradually moving towards the point of recognising intrusions upon seclusion as a freestanding basis upon which to bring an actionable privacy claim. The notion that the acquisition and publication of private information about someone may also involve an intrusion into their private affairs was not lost upon their Lordships in Campbell, where the term 'intrusion' was used on multiple occasions (albeit perhaps in some instances as a synonym for 'violation of privacy'). But it seemed clear from Campbell that an intrusion alone would not suffice to establish liability. Thus Baroness Hale distinguished between 'the sort of intrusion into what ought to be private which took place in Wainwright' and "what has been termed "the protection of the individual's informational autonomy". 45 
Lord Hoffmann offered perhaps the most expansive conception of privacy in Campbell (despite his earlier denial of a tort of privacy in Wainwright) but even he seemed to have in mind that private information would need acquiring during an intrusion as a precondition of liability. ${ }^{46}$

In some of the MOPI cases decided subsequent to Campbell, however, the courts placed greater emphasis upon the potential intrusion element involved in a MOPI, thus begging the question of whether intrusion alone would be capable of sustaining a privacy claim. In $C T B \vee N G N^{47}$ the defendant newspaper submitted that the availability on the internet of revelations concerning the claimant's identity undermined the justification for maintaining in place an injunction which prevented the press from doing likewise. Eady $\mathrm{J}$ responded that: "It is important always to remember that the modern law of privacy is not concerned solely with information or "secrets": it is also concerned importantly with intrusion. ${ }^{48}$ His Lordship explained that:

It is fairly obvious that wall-to-wall excoriation in national newspapers, whether tabloid or "broadsheet", is likely to be significantly more intrusive and distressing for those concerned than the availability of information on the Internet or in foreign journals to those, however many, who take the trouble to look it up. ${ }^{49}$

A further significant example was provided by the decision in Goodwin v NGN where Tugendhat $\mathrm{J}$ said that:

The right to respect for private life embraces more than one concept. Dr Moreham summarises what she calls the two core components of the rights to privacy: "unwanted access to private information and unwanted access to [or intrusion into] one's ... personal space" (see Law of Privacy and the Media (2nd edn, 2011, Warby, Moreham and Christie eds) paras 2.07, 2.08, 2.16 and 12.71). I shall refer to the two components of the right as "confidentiality" and "intrusion". 50

Yet despite this explicit reference by his Lordship to intrusion being conceived of as some form of unwanted access to personal space, once it came to the analysis of whether the varying of the injunction in Goodwin would lead to an intrusion, Tugendhat $\mathrm{J}$ instead appeared to equate the concept of intrusion with the infliction of distress. Indeed this same equation also seemed to be present in the $C T B$ decision where, as the quote from the case above shows, Eady $\mathrm{J}$ appeared to elide the concept of intrusion with the degree of impact that the publication would have upon the claimant and his family. The extracts from the decisions in $C T B$ and Goodwin referred to above have subsequently been cited with approval by the Supreme Court in $P J S v N G N,{ }^{51}$ a case where the potential for significant intrusion to be caused by the lifting of an injunction was cited as a justification for maintaining it in place. However this decision did little to shift the view that the references to intrusion in all of these cases meant no more than that there was a danger that publication may inflict distress upon the claimant and risk exposing them to harassment. As Lord Mance JSC put the position in PJS: 'the media storm which discharge of the 
injunction would unleash would add a different and in some respects more enduring dimension to the existing invasions of privacy being perpetrated on the internet. ${ }^{52}$ So in each of these cases the focus was upon the potential harm associated with the publication of the information, rather than with that caused by the acquiring of the information. Thus despite the references to intrusion within these cases, in practice they offer little in the way of direct support for the development of an intrusion upon seclusion tort within English law.

\section{The decisions in Gulati $v$ MGN and Vidal-Hall $v$ Google and their implications for the future application of the tort of MOPI}

The eight claimants in Gulati v MGN were all victims of so called 'phone hacking', whereby their mobile telephone voicemail messages had been surreptitiously accessed with the intention of acquiring potentially newsworthy personal information for publication in the defendant's newspapers. For the purposes of this article only one of the eight claims is pertinent, that of Alan Yentob who during the relevant period occupied a series of important positions within the British Broadcasting Corporation. Mr Yentob's claim was unusual in that the hacking of his voicemails had not directly resulted in the publication of any newspaper stories concerning him. The defendant admitted liability prior to trial. In a trial to determine quantum Mann $\mathrm{J}$ awarded $\mathrm{Mr}$ Yentob damages of $£ 85,000$, with the bulk of this being awarded for the fact of the hacking in itself. Mann J confirmed that 'damages should compensate not merely for distress ... but should also compensate (if appropriate) for the loss of privacy or autonomy as such arising out the infringement by hacking (or other mechanism) as such. ${ }^{53}$ The outcome of Mr Yentob's claim in Gulati therefore suggested that a MOPI claim could be successfully pursued where private information was wrongfully acquired without then being published (Moreham, 2015: 162). However the decision is somewhat limited in weight by the fact that liability towards Mr Yentob was admitted, and therefore neither the trial judge nor the Court of Appeal during a subsequent unsuccessful appeal by the defendant were required to directly discuss whether a MOPI claim could be successfully pursued where the information had not been published. The position implicitly established in Gulati has however received further significant support through decisions handed down during the Vidal-Hall litigation.

The claimants in the Vidal-Hall litigation had all been users of computing products produced by the Apple Corporation, and had undertaken searches upon the internet using the Safari browser installed upon these products. The browsers were set by default to block third parties from acquiring information about the nature of these searches, but through the use of what was referred to in the litigation as the 'Safari workaround' the defendant was able to acquire this information without the users' knowledge or consent. The gathered information was then used in association with the 
defendant's advertising services, meaning that whilst using the internet users could find adverts appearing in their browsers relating to previous searches undertaken by them; this clearly had the potential to cause embarrassment if another person was present when the adverts appeared, or if the same computer was later used by another member of the family. The claimants pleaded that the defendant's actions gave rise to liability in MOPI, breach of confidence and under the Data Protection Act 1998. An initial issue which ultimately required resolution by the Court of Appeal was whether England was the appropriate jurisdiction in which to try the MOPI proceedings, given that the defendant's principal place of business was in California. The defendant contended that service of the writ upon it should not be permitted, as this would amount to an abuse of the due process of the court because the MOPI claim did not give rise to a real and substantial cause of action. The Court of Appeal's response to this averment was that 'we do not think the defendant comes close to establishing that this is the position'. ${ }^{54}$ The Court continued:

On the face of it, these claims raise serious issues which merit a trial. They concern what is alleged to have been the secret and blanket tracking and collation of information, often of an extremely private nature, as specified in the confidential schedules, about and associated with the claimants' internet use, and the subsequent use of that information for about nine months. The case relates to the anxiety and distress this intrusion on autonomy has caused. ${ }^{55}$

Following this decision the defendant was granted further leave to appeal to the Supreme Court, but prior to this appeal the proceedings were settled. What was highly significant about the litigation for the purposes of this article, however, was the firm acknowledgment by both the Court of Appeal, and by the senior media judge Tugendhat $\mathrm{J}$ in the proceedings below, that a MOPI claim was even arguable in these circumstances. The pertinent feature of the claims was that, as in Mr Yentob's claim in Gulati, there had been no actual or threatened publication to a large number of people of the wrongly acquired private information. Instead, as Tugendhat $J$ described the position at first instance:

[W] hat they claim damages for is the damage they suffered by reason of the fact that the information collected from their devices was used to generate advertisements which were displayed on their screens. These were targeted to their apparent interests (as deduced from the information collected from the devices they used). The advertisements that they saw disclosed information about themselves. 56

Whilst this case might therefore have involved in a limited respect the actual or potential publication of private information to third parties, ${ }^{57}$ in the sense that others could have seen the advertisements and therefrom drawn inferences as to the claimants' internet browsing habits, there nevertheless appeared to be an acknowledgement that the very realisation that the information had been wrongly acquired was in itself actionable. Thus as we have already seen the Court of Appeal stated that the claimants' grievances concerned 'the anxiety and distress this intrusion on autonomy has caused', ${ }^{58}$ in other 
words the loss of control over the management of information concerning their internet browsing habits. Furthermore Tugendhat $\mathrm{J}$ also stated that: 'Damage is alleged to have arisen from what the claimants, and potentially third parties, have, or might have, seen on the screens of each claimant.' ${ }^{59}$ The decision in Vidal-Hall therefore offers additional support for the position that a claim in MOPI is now possible where private information has been misused in ways not involving publication.

The apparent confirmation in Gulati and Vidal-Hall of this latter point could be seen as the logical end point of a direction of travel that had already been suggested in the caselaw. A significant decision in this regard was that of the Court of Appeal in Imerman $v$ Tchenguiz $^{60}$ in 2010, which was described by the Court as being an 'old fashioned confidence' ${ }^{61}$ claim involving the filching of financial information from the claimant's computer, for use against him in divorce proceedings by his estranged wife. A notable feature of the case was that the confidential financial information was not acquired with a view to publication. Lord Neuberger MR confirmed that this represented no bar to a claim in breach of confidence: 'looking at documents which one knows to be confidential is itself capable of constituting an actionable wrong', ${ }^{62}$ Whilst the point made by his Lordship here strictly only applied to claims for breach of confidence, there was nevertheless an indication in the judgment that human rights considerations may dictate that this position should also prevail in MOPI claims: 'the law should be developed and applied consistently and coherently in both privacy and "old fashioned confidence" cases, even if they sometimes may have different features." ${ }^{63}$ In addition to the decision in Imerman it was significant that in several MOPI cases statements had been made to the effect that Articles 8 and 10 now represented 'the very content of the domestic tort that the English court has to enforce', ${ }^{64}$ and it was patently clear from Strasbourg jurisprudence that Article 8 could be engaged where private information had been merely acquired, without any ensuing publication. A leading authority in this regard, which was cited with apparent approval by the Court of Appeal in both Imerman and Vidal-Hall, was the decision of the ECtHR in Copland $v$ United Kingdom ${ }^{65}$ where the applicant, the Personal Assistant to a College Principal, was unjustifiably subjected to the monitoring of her work based telephone, email and internet usage by the Deputy Principal of the college. A further example is provided by the well-known decision in Halford $v$ United Kingdom ${ }^{66}$ where the former Assistant Chief Constable of Merseyside Police was able to establish that the interception by Merseyside Police of calls made from her office telephone amounted to a violation of Article 8 .

The implications of the decisions in Gulati and Vidal-Hall in the context of English law are thus significant, because they suggest that it is now possible for individuals to pursue a MOPI claim before the English courts in precisely those circumstances where in both Ontario and New Zealand it was felt that an appropriate remedy would only become available through the recognition of an intrusion upon 
seclusion tort. So in Jones the defendant through her actions acquired, but did not publish, private financial information about the plaintiff for personal misuse; similarly in $C v$ Holland the defendant was able to acquire, but did not publish, private information concerning the plaintiff's undressed appearance, again for personal misuse. If one turns to the proposals of the ALRC, here too it would appear that the post-Gulati/Vidal-Hall MOPI tort would now cover much of the ground intended to be occupied by the ALRC's proposed intrusion tort (2014: para. 5.2):

\footnotetext{
Intrusion upon seclusion will usually involve watching, listening to, or recording someone's private activities or private affairs. It can also involve unwanted physical intrusion into someone's private space. Examples might include taking a photo of someone in a change room, reading their bank statements, tapping their phone calls, or hacking into their computer.
}

It would therefore appear that, provided the grievance at hand could be accommodated within an informational paradigm, there would then be no necessity to press the case for the recognition of an intrusion upon seclusion tort before a judge in English proceedings. It is at this juncture, however, that the limitations of the decisions in Gulati/Vidal-Hall may become apparent, because the point just made begs two questions, which are: first, what is the breadth, in privacy terms, of the informational paradigm; and secondly, if there are privacy violating situations falling outside the scope of the informational paradigm then, realistically speaking, does this make out a case for the recognition of an intrusion upon seclusion tort in order to address these voids? These questions require separate consideration.

\section{The scope and adequacy of protection for privacy afforded by an informational paradigm}

Certain theorists have suggested that an informational approach affords comprehensive protection for privacy. For example Meeler (2008: 153) has argued that informational privacy is 'the only meaningful core of privacy interests. My reasons for focusing on information are straightforward: I suggest that any private matter must be related to this aspect, and that protecting information privacy is sufficient for protecting the other aspects'. Thus on Meeler's account: 'When we allow any access to you, we allow others to have some information about you. Consequently, if we protect all information about you, then we protect all access to you' (2008: 160). Meeler's conception of 'access' is clearly not synonymous with that of 'intrusion upon seclusion', as evidenced by his example where he suggests that if an intimate photograph of someone was stored on a database somewhere, then anyone who accessed the photograph would obtain intimate information about that person without ever invading their 'access privacy' (2008: 160). In contrast, as seen in cases such as Jones $v$ Tsige, under an intrusion approach the 'accessing' of the database can in itself amount to a violation of privacy. Nevertheless from a protectionist perspective Meeler's central point remains potentially valid, namely 
that if an individual's private information can be protected then this may offer sufficient protection for their privacy in overall terms. A similar approach has been advocated by Powers (1996), who has argued that much of what is contained within accounts of privacy focusing upon restricted access to the self can in fact be encompassed within a concept of 'cognitive inaccessibility', meaning that only an informational aspect of the person is essentially involved in any privacy loss. Powers argued that: 'Although increased physical access often is instrumental in gaining cognitive access, treating physical inaccessibility as a separate dimension of privacy only highlights what is contingent rather than what we have shown to be essential to or sufficient for a privacy loss' (1996: 381).

Against these approaches it has been argued that a focus upon information may fail to protect privacy in crucial situations. Inness (1992: 62) offered the following example:

[W]hen a peeping Tom looks in a person's window for the second time, it is conceivable that he might acquire absolutely no new information about the victim. Despite this failure, the peeping Tom clearly violates the victim's privacy with the second, as well as the first, inspection. When he is charged with the second violation, he cannot escape with the explanation, "I've seen it all before!"’.

Similarly Johnson (1992: 273) has contended that: 'The private detective grossly violates your privacy, not just attempts to, by putting a tap on your phone, even if you're out of the country and he never hears anything.' Johnson's example reminds us of the decision in Hamberger $v$ Eastman referred to earlier, ${ }^{67}$ where it was found that the installation of a bugging device in a bedroom represented an intrusion upon seclusion, irrespective of whether anyone had actually listened to or overheard any sounds or voices emanating therefrom. However what is significant about Inness's example is that the intention behind the second peeping was nevertheless to acquire information. The peeping Tom doesn't just look into the window in vain, but because he wants to see something, and just because he's seen it all before might not necessarily quench his desire to see it all again. The aphorism 'a picture is worth a thousand words' referred to by several of their Lordships in Campbell would apply equally well here if adapted to 'a visual image is worth a thousand mental recollections'. It would thus seem that there would still be scope for a MOPI claim in the peeping Tom example. To place this point within the context of the existing MOPI caselaw, if this morning a newspaper published a covertly taken photograph of the musician Paul Weller's children whilst out on a family shopping trip, it would hardly behove the newspaper to argue that no MOPI claim would lie here because the public had 'seen it all before' (the public would have seen it before because previously in October 2012 photographs of a Weller family shopping trip were published in the Mail Online, which resulted in a successful claim for MOPI, see Weller $v$ Associated Newspapers). ${ }^{68}$ 
Whether a MOPI claim would be possible in situations such as those covered by the facts in Hamberger and Johnson's phone tap example is more problematic. If one puts aside the contention that an alternative remedy may be available in these circumstances in any event, such as in trespass, then logic and a need for compatibility with Article 8 jurisprudence suggests that a MOPI claim should still be arguable here. The MOPI caselaw makes it clear that individuals possess a reasonable expectation that information relayed in a phone call, ${ }^{69}$ or as to what transpires within their bedrooms, ${ }^{70}$ should not be acquired by other citizens without consent. So if it was discovered that there had been a concerted attempt to acquire this information through the use of some device, this should surely still infringe a reasonable expectation of privacy, even if no information (or no relevant information) was actually acquired. That this should be the position is now reinforced by the Court of Appeal decisions in Gulati and Vidal-Hall where in both cases there was an emphasis upon how there had been an intrusion upon informational autonomy, or a 'diminution of a right to control formerly private information'; ${ }^{71}$ the placing of listening devices would undoubtedly lead to a loss of control over private information. From the ECHR perspective it would seem inconceivable that Article 8 would not be engaged where an attempt was made to acquire information through the covert use of a listening device. That this is the position would appear to be borne out by decisions such as Klass $v$ Federal Republic of Germany, ${ }^{72}$ concerning the surveillance of telephone calls, as well as the decisions in Copland and Halford discussed earlier. These cases would appear to also confirm that the monitoring of calls will engage Article 8 irrespective of whether the monitoring leads to the acquisition of only anodyne information. In sum, therefore, the informational paradigm may be viewed as one which is extremely broad in scope, and a tortious action capable of remedying violations of informational autonomy would also appear to be capable of offering redress in many situations where it was alleged that there had been an intrusion upon seclusion.

Nevertheless it is conceded that there may be certain legitimate privacy complaints that would not be comfortably accommodated within an informational paradigm, such as the circumstances which occurred in Wainwright outlined earlier on in this article. Here the complaints were not borne out of an objection that the officers that had strip-searched the claimants had wrongly acquired private information about them; nor, realistically, had the officers even aimed to acquire private information about the claimants through their breach of the prison rules. Instead the claimants were objecting to the manner of their treatment, which engendered a violation of their dignity, and led to feelings of vulnerability and distress through having to stand virtually naked before state officials. The case shares some similarities with the US intrusion decision of Hill $v$ McKinley considered earlier. ${ }^{73}$ Given therefore that there may be outliers under an informational approach, does this accordingly make out a case for the recognition of an intrusion upon seclusion tort within England and Wales? The first point to note is that a 
case such as Wainwright would nowadays attract a remedy under the HRA, given that the prison officers would be representatives of a public authority, and given also that it was subsequently confirmed by the ECtHR in Wainwright $v$ United Kingdom ${ }^{74}$ that the officers' actions amounted to a violation of Article 8. It is perhaps unlikely that a Wainwright-type complaint would arise from the actions of a private actor (i.e. a doctor acting under a private healthcare agreement) in the absence of that person having a voyeuristic (and therefore informational) motivation for subjecting an individual to such inappropriate behaviour. ${ }^{75}$ It follows therefore that there may in fact be few situations where a claimant would even need to appeal to a judge in English proceedings for the recognition of an intrusion upon seclusion tort. But even if such a case did emerge, and even if the judge was minded to be sympathetic to the claim, it is suggested that it would be unlikely that the judge would afford a remedy through the recognition of a US style intrusion upon seclusion tort, as the judges did in Jones $v$ Tsige and $C v$ Holland. Instead, the 'common law's perennial need ... to appear not to be doing anything for the first time ${ }^{76}$ makes it much more likely that any English judge would craft a remedy through the conventional process of the incremental development of the common law, and in this regard the most obvious cause of action through which to evolve the common law would be the tort of MOPI. In consequence, it may therefore ultimately transpire that the reasonable expectation of privacy test within the tort of MOPI may need broadening out to encompass those (admittedly perhaps infrequent) circumstances where privacy could be said to have been invaded in a purely non-informational dimension alone.

\section{Conclusion}

In the foregoing discussion it has been argued that developments within the tort of MOPI make it unlikely that a US style tort of intrusion upon seclusion will be developed within England and Wales in the near future, given that MOPI claims may now apparently be brought in non-publication scenarios, and given also the potential reach of the informational paradigm. Nevertheless it has been conceded that there may be circumstances where individuals may legitimately feel that their privacy has been violated, but where it may be artificial to shoehorn their complaint within the informational paradigm. It has been suggested that the English courts are more likely to respond to these situations by incrementally evolving the tort of MOPI, rather than by importing an intrusion upon seclusion tort into English law. Such incremental development would also be more harmonious with the European Human Rights theme which has provided the context for the growth of the tort of MOPI. ${ }^{77}$ Whilst this form of incremental development may attract the concern that it would produce a law of uncertain scope ${ }^{78}$ this would be offset by the opportunities it would afford for the adoption of a more nuanced approach towards the protection of privacy. To take the example of Wainwright again, it was suggested earlier that the complaint in this case wasn't really about information; but it is arguable that neither was it really about an intrusion into some 
sort of space or zone. Instead the complaint was about a violation of personal dignity, resulting in an interference with psychological integrity. The notion of respect for psychological integrity is one which is well recognised within the Article 8 jurisprudence, ${ }^{79}$ and English judges are now acquainted with this interest through claims under the HRA $1998{ }^{80}$ It would therefore be more appropriate, it is suggested, if English tort law were to be developed so as to offer respect for Article 8 privacy interests such as these, rather than to instead focus narrowly upon the means through which these interests might have been violated. ${ }^{81}$ Viewed from the ECHR perspective, the information/intrusion bifurcation appears to be a rather crude approach towards the protection of privacy. ${ }^{82}$ Moreover, as suggested earlier on in the context of the ALRC's proposals, ${ }^{83}$ the information/intrusion approach may generate messy arguments over precisely how someone's privacy has been violated, thus detracting from the question of whether the victim may claim that their privacy has been violated in the first place. Instead, a focus upon whether the victim had a reasonable expectation that their privacy interests would be respected, irrespective of how those expectations might have been defeated, would offer a more enlightened basis upon which to analyse whether and in what ways the law may offer protection for privacy. Indeed, because the ECtHR has confirmed that there may be positive obligations inherent in an effective respect for private or family life, ${ }^{84}$ and because these "may involve the adoption of measures designed to secure respect for private life even in the sphere of the relations of individuals between themselves', ${ }^{85}$ the development of the MOPI tort along the lines suggested above may ultimately become a mandatory requirement if the United Kingdom is to maintain conformity with these positive obligations. ${ }^{86}$

\section{Acknowledgements}

The author would like to thank the anonymous peer reviewers and editorial committee for their helpful feedback upon an earlier draft of this article.

\section{Conflict of interest}

The author declared no potential conflicts of interest with respect to the research, authorship, and/or publication of this article.

\section{Funding}

The author received no financial support for the research, authorship, and/or publication of this article. 


\section{Notes}

${ }^{1}$ As good a stepping stone as any into this debate and the accompanying literature is offered by Solove (2014).

${ }^{2}$ See eg from England and Wales the report of the Younger Committee (1972), and from New Zealand the Law Commission's report (2008).

${ }^{3}$ ABC v Lenah Game Meats Ltd (2001) 208 CLR 199.

${ }^{4}$ [2014] EWHC 13 (QB), [2014] 1 WLR 4155, on appeal at [2015] EWCA Civ 311, [2016] QB 1003.

5 [2015] EWHC 1482 (Ch), on appeal at [2015] EWCA Civ 1291, [2017] QB 149.

${ }^{6}$ Prosser was referring to a phrase used by Cooley (1880: 29).

${ }^{7}$ See eg Page (2010).

${ }^{8}$ In relation to Australia, for example, the matter is discussed relatively briefly in the Final Report of the Australian Law Reform Commission (2014: 87).

${ }^{9}$ Restatement (1977), comment $a$. upon $\S 652$ B 'Intrusion upon Seclusion'.

109 N.W. 146 (1881).

11311 F.3d 899 (2002).

${ }^{12}$ Restatement (1977), comment $b$. upon $\S 652 \mathrm{~B}$.

13983 N.E.2d 414 (2012).

${ }^{14}$ Restatement (1977), comment $b$. upon $\S$ 652B (emphasis supplied).

15206 A.2d 239 (1964).

${ }^{16}$ Restatement (1977), § 652D 'Publicity Given to Private Life'.

17550 F.Supp. 525 (1982).

18 Restatement (1977), comment $a$. upon $\S 652 \mathrm{D}$.

${ }^{19}$ Restatement (1977), comment $d$. upon $\S 652 \mathrm{~A}$ 'General Principle'.

${ }^{20}$ See eg Jones $v$ US Child Support Recovery 961 F.Supp. 1518 (1997) District Court Utah Division, where the publicity of private matters claim was dismissed due to the information being disclosed to only the 
plaintiff's employer and a few close relatives, whereas the intrusion upon seclusion claim was allowed to proceed to trial.

${ }^{21}$ In the common law provinces of British Columbia, Manitoba, Newfoundland and Saskatchewan statutory privacy torts have been enacted, although these are general in nature on their wording and do not explicitly differentiate between informational and intrusional violations of privacy.

222012 ONCA 32. See Hunt (2012).

${ }^{23}$ See eg Saccone v Orr (1981) 34 O.R. (2d) 317 (Ont Co Ct).

${ }^{24}$ Athans $v$ Canadian Adventure Camps Ltd (1977) 17 O.R. (2d) 425 (Ont HC).

${ }^{25}$ Jane Doe $464533 v$ ND 2016 ONSC 541 (Ontario Superior Court of Justice). Judgment in this case was entered in default, but this was successfully appealed by the defendant and at the time of writing it is unclear whether this case will now proceed to a fully contested trial.

${ }^{26}$ Jones (n. 22), at [21].

${ }^{27}$ For an analysis of Sharp JA's reasoning see Bennett (2013).

${ }^{28}$ Jones (n. 22), at [71].

${ }^{29}$ [2012] NZHC 2155. For discussion of the decision see Hunt (2013).

${ }^{30}$ [2005] 1 NZLR 1.

${ }^{31}$ C v Holland (n. 29), at [89].

${ }^{32}$ Ibid. at [86].

${ }^{33}$ Ibid. at [94].

${ }^{34}$ Ibid. at [97].

${ }^{35} \mathrm{Ibid}$. at [94].

${ }^{36}$ For discussion of the state of the lower court authorities see the final report of the Australian Law Reform Commission (2014: paras 3.53-3.58).

${ }^{37}$ Quoting from para. 3.68 of Warby et al (2011).

38 [2004] UKHL 22, [2004] 2 AC 457.

39 [2015] EWCA Civ 311, [2016] QB 1003, at [51].

40 [2003] UKHL 53, [2004] 2 AC 406.

41 [1979] Ch 344, at 372.

${ }^{42}$ Campbell (n. 38), at [133].

${ }^{43}$ See eg Phillipson (2007).

44 [2006] EWCA Civ 1714, [2008] QB 73, at [11].

${ }^{45}$ Campbell (n. 38), at [134].

${ }^{46}$ Ibid. at [75].

${ }^{47}$ [2011] EWHC 1326 (QB).

${ }^{48}$ Ibid. at [23].

${ }^{49} \mathrm{Ibid}$. at [24].

50 [2011] EWHC 1437 (QB), [2011] HRLR 31, at [85]. See also Tugendhat J's further reference to the concept of intrusion in a subsequent hearing in the case of CTB $v N G N$ [2011] EWHC 1334 (QB).

${ }^{51}$ [2016] UKSC 26, [2016] 2 WLR 1253.

52 Ibid. at [45] (emphasis supplied).

53 [2015] EWHC 1482 (Ch), at [168].

54 [2015] EWCA Civ 311, [2016] QB 1003, at [136].

${ }^{55}$ Ibid. at [137].

${ }^{56}$ [2014] EWHC 13 (QB), [2014] 1 WLR 4155, at [23] (emphasis supplied).

${ }^{57} \mathrm{I}$ am grateful to one of the anonymous reviewers for highlighting that strictly the data itself would not be published here, but instead it would be used to generate advertisements from which inferences could be drawn in respect of private matters.

${ }^{58}$ Vidal-Hall (Court of Appeal) (n. 54), at [137] (emphasis supplied). 
${ }^{59}$ Vidal-Hall (Queen's Bench) (n. 56), at [77] (emphasis supplied).

${ }^{60}$ [2010] EWCA Civ 908, [2011] Fam 116.

${ }^{61} \mathrm{Ibid}$. at [67] (Lord Neuberger MR).

${ }^{62} \mathrm{Ibid}$. at [68].

${ }^{63} \mathrm{Ibid}$. at [67]

${ }^{64}$ McKennitt v Ash [2006] EWCA Civ 1714, [2008] QB 73, at [11] (Buxton LJ).

${ }^{65}$ (2007) 45 EHRR 37.

${ }^{66}$ (1997) 24 EHRR 523.

${ }^{67}$ See text to $n .15$ above.

${ }^{68}$ [2014] EWHC 1163 (QB), [2014] EMLR 24.

${ }^{69}$ See eg Gulati (hacking of mobile telephone voicemail messages).

${ }^{70}$ See eg Mosley v NGN [2008] EWHC 1777 (QB), [2008] EMLR 20 (the events video-recorded in this case occurred in a flat used for sexual activities, but the outcome would have been the same had they occurred in the claimant's bedroom).

${ }^{71}$ Gulati (n. 4), at [48] (Arden LJ, emphasis supplied).

72 (1979-80) 2 EHRR 214.

${ }^{73}$ See text to $n .11$ above.

${ }^{74}$ (2007) 44 EHRR 40.

${ }^{75}$ See eg a report in The Guardian of a doctor using their mobile telephone to surreptitiously film patients during inappropriately conducted medical examinations: Morris and Hayhurst (2013).

${ }^{76}$ Douglas and Others v Hello! Ltd [2001] 2 WLR 992, [2001] QB 967 (CA), at 998 (Sedley LJ).

${ }^{77}$ For discussion of the influence of human rights law upon the tort see Giliker (2014).

${ }^{78}$ See eg the concerns in this regard of the Australian Law Reform Commission (2014: paras 5.78 - 5.85).

${ }^{79}$ See eg Von Hannover $v$ Germany (2005) 40 EHRR 1, at [50].

${ }^{80}$ See eg $R$ (Wood) $v$ Comr of Police of Metropolis [2009] EWCA Civ 414, [2010] 1 WLR 123, at [20].

${ }^{81}$ Moreham (2014) also calls for the development of the tort of MOPI in order that it may protect what she conceptualises as 'physical privacy', which takes the form of unwanted sensory access through watching, listening to or otherwise sensing someone against their wishes. Moreham differentiates physical privacy from intrusions on the basis that the former describes what is protected, whereas the latter describes a particular kind of privacy interference. In contrast, the position being argued for in this article is for the eventual protection of 'privacy interests' in a broader Article 8 sense, where this is deemed necessary, rather than for the eventual dual protection of both informational privacy and Moreham's physical privacy category. See also Moreham (2015).

${ }^{82}$ See Hunt (2012), who agrees that 'it is not sensible to have two separate torts - one to protect against intrusions and one for disclosures. Rather, one tort should capture both scenarios' (at 673).

${ }^{83}$ See text to $n .37$ above.

${ }^{84} X$ and $Y v$ The Netherlands (1986) 8 EHRR 235.

${ }^{85}$ Von Hannover $v$ Germany (2005) 40 EHRR 1, at [57].

${ }^{86}$ A point also made by Moreham (2014) in the context of her hope that the MOPI tort may in due course be extended to address violations of 'physical' as well as informational privacy.

\section{References}

American Law Institute (1977) Restatement of the Law Second, Torts, volume 3. St. Paul, Minn: American Law Institute Publishers.

Australian Law Reform Commission (2014) Serious Invasions of Privacy in the Digital Era. Final Report, no. 123, Sydney, Australia, 30 June. 
Bennett T (2013) Privacy, Corrective Justice, and Incrementalism: Legal Imagination and the Recognition of a Privacy Tort in Ontario. McGill Law Journal 59(1): 49-94.

Bennett T (2014) Emerging privacy torts in Canada and New Zealand: an English perspective. European Intellectual Property Review 36(5): 298-305.

Cooley TM (1880) A Treatise on the Law of Torts or the Wrongs Which Arise Independently of Contract. Chicago: Callaghan.

Giliker P (2014) English tort law and the "tort" of breach of confidence. Juridical Review [2014](1): 1526.

Home Office, Lord Chancellor's Office, Scottish Office (1972) Report of the Committee on Privacy. Cmnd. 5012, July. London: Stationary Office.

Hunt C (2012) Privacy in the Common Law: A Critical Appraisal of the Ontario Court of Appeal's Decision in Jones v. Tsige. Queen's Law Journal 37(2): 665-695.

Hunt C (2013) New Zealand's New Privacy Tort in Comparative Perspective. Oxford University Commonwealth Law Journal 13(1): 157-166.

Inness J (1992) Privacy, Intimacy and Isolation. New York: Oxford University Press.

Johnson J (1992) A Theory of the Nature and Value of Privacy. Public Affairs Quarterly 6(3): 271-288.

Meeler D (2008) Is Information All We Need to Protect? The Monist 91(1): 151-169.

Moreham NA (2014) Beyond Information: Physical Privacy in English Law. Cambridge Law Journal 73(2): 350-377.

Moreham NA (2015) Liability for listening: why phone hacking is an actionable breach of privacy. Journal of Media Law 7(2): 155-169.

Morris S and Hayhurst C (2013) Torbay hospital doctor jailed over secret photographs of female patients. The Guardian, 4 October, 2013, UK edition. Available at: www.theguardian.com/uknews/2013/oct/04/torbay-hospital-doctor-jailed-secret-photos-patients (accessed 27 April 2017).

New Zealand Law Commission (2008) Privacy: Concepts and Issues. Study Paper 19, Wellington, New Zealand, January.

Page J (2010) American tort law and the right to privacy. In: Brüggemeier G, Ciacchi AC and O'Callaghan P (eds) Personality Rights in European Tort Law. Cambridge: Cambridge University Press, pp.38-72.

Phillipson G (1999) The Human Rights Act, 'Horizontal Effect' and the Common Law: a Bang or a Whimper? Modern Law Review 62(6): 824-849.

Phillipson G (2007) Clarity postponed: horizontal effect after Campbell. In: Fenwick H, Phillipson G and Masterman R (eds) Judicial Reasoning under the UK Human Rights Act. Cambridge: Cambridge University Press, pp.143-173.

Powers M (1996) A Cognitive Access Definition of Privacy. Law and Philosophy 15(4): 369-386.

Prosser WL (1960) Privacy. California Law Review 48(3): 383-423.

Solove DJ (2008) Understanding Privacy. Cambridge: Harvard University Press.

Warby M et al (2011) Tugendhat and Christie: The Law of Privacy and The Media. Oxford: Oxford University Press.

Warren SD and Brandeis LD (1890) The Right to Privacy. Harvard Law Review 4(5): 193 -220. 